\title{
Recurrent spontaneous fetal loss (RSFL) pada sindrom antifosfolipid
}

\author{
John J. E. Wantania \\ Bagian/SMF Obstetri dan Ginekologi Fakultas Kedokteran \\ Universitas Sam Ratulangi - RSUP Prof. R. D. Kandou Manado \\ Email: john_w_md@yahoo.com
}

\begin{abstract}
Approximately 40-50\% causes of recurrent spontaneous fetal death, often called the recurrent spontaneous fetal loss (RSFL), could not be identified so far. Antiphospholipid syndrome itself is one of the most common causes of RSFL and is responsible for approximately $16-36 \%$ of patients with RSFL. Various factors associated with the occurrence of the RSFL in APS are as follows: intrauterine growth restriction (IUGR), preeclampsia, premature placental separation, DVT, HELLP, and DIC at a normal fetal karyotype. Diagnosis includes clinical and laboratory criteria. Additional laboratory examinations have been developed and used to improve the predictive power and diagnostics. Repeat aPL antibodies examination may be required to increase the sensitivity and specificity of diagnosis. Other treatment options include the use of anticoagulants, corticosteroids, or any other modalities with regard to obsterics conditions.
\end{abstract}

Keywords: recurrent spontaneus fetal loss, APS

\begin{abstract}
Abstrak: Sekitar 40-50\% penyebab terjadinya kematian janin spontan berulang atau sering disebut pula dengan Recurrent Spontaneous Fetal Loss (RSFL) sampai saat ini tidak dapat diidentifikasi. Sindrom antifosfolipid sendiri adalah salah satu penyebab paling umum terjadinya RSFL dan bertanggung jawab pada sekitar 16-36\% pasien dengan RSFL. Berbagai faktor yang terkait dengan terjadinya RSFL pada APS meliputi pertumbuhan janin intrauterin yang terhambat (IUGR), preeklampsia, pemisahan plasenta prematur, DVT, HELLP, dan DIC pada kariotipe janin yang normal. Diagnosis mencakup kriteria klinis dan laboratorium. Pemeriksaan laboratorium tambahan telah dikembangkan dan digunakan untuk meningkatkan kekuatan prediksi dan diagnostik. Pemeriksaan antibodi aPL berulang mungkin diperlukan untuk meningkatkan sensitivitas dan spesifisitas diagnosis. Pilihan penanganan antara lain dengan penggunaan antikoagulan, kortikosteroid, atau pun modalitas lain dengan tetap memperhatikan kondisi obsterik.
\end{abstract}

Kata kunci: kematian janin spontan berulang, APS

Sindrom antifosfolipid (Antiphospholipid syndrome; APS) adalah suatu gangguan autoimun, dengan trombosis berulang atau morbiditas obstetrik. APS pertama kali ditemukan tahun 1983. ${ }^{1-3}$

Angka kejadian APS (di Amerika Serikat) belum diketahui. Satu sampai lima persen dari individu sehat mempunyai antibodi antifosfolipid (aPL) sedangkan antibodi antikardiolipin (aCL) lebih sering ditemukan pada orang tua, dan harus berhati-hati pada hasil titer positif.
Antibodi aPL ditemukan 30-40\% pada pasien dengan systemic lupus erythematosus (SLE), namun hanya sekitar 10\% yang menderita APS. Kurang lebih setengah kasus APS tidak selalu berkaitan dengan penyakit reumatik lainnya. Dalam penelitian pada 100 pasien dengan trombosis vena tanpa riwayat SLE, antibodi aCL ditemukan pada $24 \%$ dan antibodi lupus/lupus anticoagulant (LA) pada $4 \%$ sampel. $^{3}$ 


\section{EBM kejadian keguguran berulang}

Prevalensi antibodi aPL pada wanita usia muda dengan tampilan yang sehat sekitar 1-5\%. Pada SLE, aPL ditemukan sekitar 12-34\%. Pada pasien SLE yang diikuti dalam jangka waktu yang lebih lama, sekitar 50\% pasien menunjukkan antibodi aPL. Antibodi LA dan aCL juga ditemukan pada berbagai kasus medis seperti penyakit autoimun, kelainan jaringan ikat dan beberapa keadaan lain seperti penggunaan obat-obatan, keganasan, infeksi, dan beberapa penyakit sistemik. Frekuensi dan interpretasi bergantung pada sensitifitas berbagai pemeriksaan yang digunakan. Antibodi aPL (APA) positif juga ditemukan pada penderita idiopathic thrombocytopenic purpura (ITP), wanita usia tua, dan 5-10\% darah donor yang normal. ${ }^{4}$

\section{Patofisiologi}

Mekanisme terjadinya trombosis pada pasien APS belum jelas, beberapa teori mencakup penurunan aktivitas plasminogen, peningkatan agregasi platelet, inhibisi prostasiklin dan protein $\mathrm{C}$, serta peningkatan faktor VIII. ${ }^{3}$

Satu hipotesis menyebutkan adanya defek dalam apoptosis seluler, yang emaparkan fosfolipid membran pada pengikatan berbagai protein plasma, seperti beta-2 glikoprotein membentuk kompleks fosfolipid-protein saat sudah terikat, dan neoepitop terbuka yang selanjutnya menjadi target autoantibodi. ${ }^{3}$ Bukti terbaru mengatakan bahwa beta-2 glikoprotein I teroksidasi dapat berikatan dan mengaktivasi sel dendritik dengan cara yang sama seperti aktivasi yang dipicu oleh toll-like receptor 4 (TLR-4), yang dapat meningkatkan produksi autoantibodi. ${ }^{3}$ Mekanisme lain yang mungkin untuk terjadinya hiperkoagulasi dari antibodi aPL ialah: ${ }^{3}$

- produksi antibodi yang melawan faktor koagulasi, meliputi protrombin, protein $\mathrm{C}$, protein S, dan anneksin.
- aktivasi trombosit untuk meningkatkan penempelan endotel.

- aktivasi endotel vaskuler yang dapat memfasilitasi pengikatan trombosit dan monosit.

- reaksi antibodi untuk mengoksidasi low density low protein, yang menjadi predisposisi terjadinya arterosklerosis dan infark miokardium.

Bukti baru menyatakan bahwa aktivasi komplemen yang dimediasi oleh aPL, kemungkinan merupakan penyebab primer kejadian abortus. ${ }^{3}$

Tabel 1. Beberapa mekanisme patogen dari $\mathrm{aPL}^{5}$

Inhibition of anticoagulant reactions

Inhibition of $\beta 2 \mathrm{GPI}$ anticoagulant activity

Inhibition of the protein $C$ pathway

Inhibition of protein $C$ activation

Inhibition of activated protein C

Inhibition of antithrombin activity

Displacemnet of annexin A5

Cell-mediated events

On endothelial cells

Enhanced endothelial cell procoagulant activity

Increased expression and activation of tissue factor

Expression of adhesion molecules

Impaired fibrinolysis

Dysregulation of eicosanoids

Decreased endothelial cell prostacyclin production

Increased platelet thromboxane A2 production

Impaired function of endothelial nitric oxide synthase

On monocytes

Expression of tissue factor

Increase oxidative stress

On platelets

Enhanced platelet activation/eggregation

On plasmocytoid dendritic cells

Increased expression of toll-like receptor 7 and toll-like receptor 8 


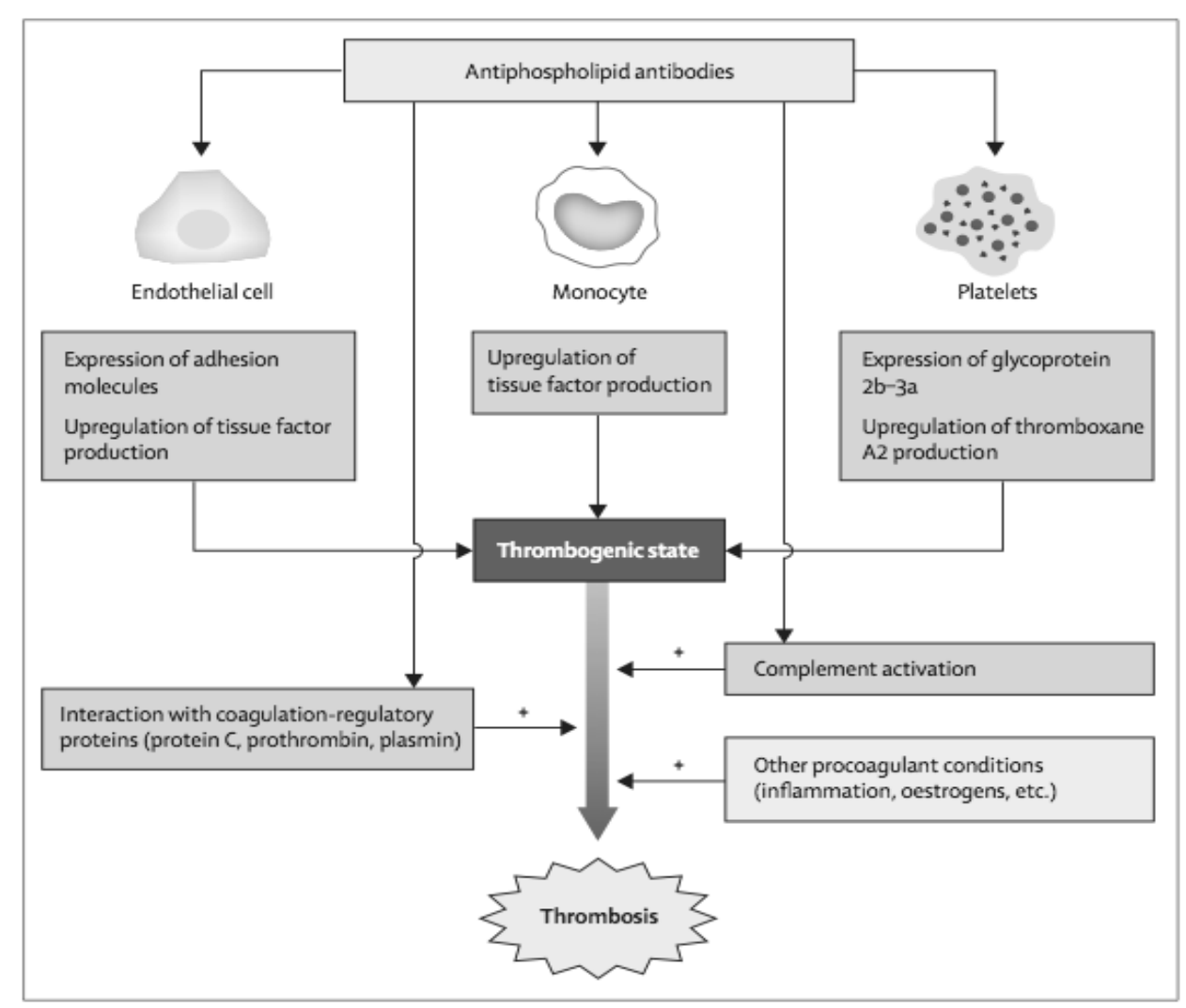

Gambar 1. Patogenesis trombosis pada APS. Sumber: Greaves M, $1999 .^{6}$

\section{Mekanisme terjadinya keguguran berulang}

Adanya trombosis pada plasenta menjelaskan berbagai manifestasi klinis. Antibodi aPL dapat menginduksi trombosis intervilus dan infark intervilus sehingga mengganggu perfusi plasenta. Antibodi juga memengaruhi jaringan sitotrofoblas in vitro. Antibodi ini menghambat prostasiklin, mengurangi protein $\mathrm{C}$, memroduksi vilitis kronis dan atau infiltrasi plasma sel desidual. Annexin A5 dan A2 yang terdapat pada plasenta berfungsi sebagai antikoagulan. Antibodi aPL menghambat annexin dan menyebabkan trombosis. Annexin A5 secara normal menutupi permukaan anionik trombogenik dan menghambat aktivasi faktor $\mathrm{X}$ dan protrombin. Antibodi aPL/ $\beta 2 \mathrm{gp} 1$ dapat merusak pelindung trofoblas dan sel endotel selapis. ${ }^{4}$

Antibodi aPL menyebabkan respon inflamasi lokal yang berperan dalam keguguran. Antibodi ini menyerang desidua maternal dan menginvasi trofoblas secara langsung; hal ini merusak plasentasi fetus. Antibodi dapat menyebabkan kerusakan sel, apoptosis, inhibisi proliferasi dan pembentukan sinsitia, serta menurunkan produksi hCG. ${ }^{4}$

\section{Kriteria diagnosis}

Kriteria diagnosis APS berdasarkan International Consensus Classification, ialah sebagai berikut: ${ }^{7}$ APS terjadi bila terdapat satu dari kriteria klinis dan satu dari kriteria laboratorium terpenuhi.

\section{Kriteria klinis}

1. Trombosis vaskular

2. Morbiditas kehamilan

a) Satu atau lebih kematian janin yang tidak dapat dijelaskan penyebabnya pada janin dengan morfologi normal pada usia kehamilan diatas 10 minggu dengan menggunakan ultrasonografi atau pemeriksaan 
langsung pada janin.

b) Satu atau lebih persalinan prematur pada neonatus dengan morfologi normal sebelum usia kehamilan 34 minggu karena pre eklampsia berat, eklampsia, atau insufisiensi plasenta.

c) Tiga atau lebih abortus spontan berturut-turut yang tidak dapat dijelaskan penyebabnya terjadi sebelum minggu ke-10 kehamilan (dengan ekslusi dari kelainan anatomi dan hormonal ibu dan penyebab kromosom ayah dan ibu).

\section{Kriteria laboratorium}

1. Adanya lupus anticoagulan di dalam plasma pada dua kali atau lebih pemeriksaan paling sedikit berjarak 12 minggu, atau

2. Adanya isotop IgM dan IgG antibodi aCl pada serum atau plasma dengan titer medium atau tinggi ( $>40 \mathrm{GPL}$ atau MPL atau persentil $>99^{\text {th }}$ ), pada dua atau lebih pemeriksaan paling sedikit berjarak 12 minggu, atau

3. Adanya isotop antibodi IgM dan atau IgG Anti- $\beta_{2}$ glikoprotein-I pada serum atau plasma (dengan titer lebih dari persentil $90^{\text {th }}$ ) pada dua atau lebih pemeriksaan paling sedikit berjarak 12 minggu.

Masalah obstetri pada pasien demikian meliputi preeklampsia, eklampsia, trombosis plasenta, dan kelahiran prematur. Komplikasi obstetri yang jarang dilaporkan ialah sindrom HELLP (Hemolysis, elevated liver enzymes, and low platelets) yang terjadi pada 0,01-0,2\% kehamilan; 10-20\% pada preeklampsia berat dan eklampsia. ${ }^{1,8}$

Beberapa manifestasi klinis yang mungkin terjadi akibat antibodi antifosfolipid antara lain: ${ }^{4}$

- Tromboemboli arteri dan vena asimtomatik: osteonekrosis avaskular

- Hematologik berupa sitopenia: trombositopenia, anemia hemolitik autoimun, leukopenia.

- Koagulopati: disfungsi trombosit, defisiensi protrombin, lupus anticoagulant

- Neurologik: iskemia akut (cerebrovascular accident, transient ischemic attack, ensefalopati); migrain parah; infark multipel demensia; disfungsi kognitif; dan kejang

- Dermatologik: livedo reticularis; acrocyanosis (iskemia kulit distal, ulkus, gangren); nekrosis kulit luas; lesi kulit seperti pioderma gangrenosum; anetoderma

- Cardiopulmonar: marantic endocarditis; iskemia dan infark miokard; massa trombotik intrakardial; penyakit arteri perifer; tromboemboli dan hipertensi pulmonal nontrombotik

- Obstetrik: aborsi spontan berulang; pertumbuhan janin terganggu; preeklamsia; chorea gravidarum; skor Apgar rendah; persalinan prematur.

\section{Penyulit-penyulit obstetrik terkait APS}

\section{Manifestasi obstetrik}

Sindrom antifosfolipid adalah salah satu penyebab paling umum terjadinya kematian janin spontan berulang atau sering disebut pula dengan Recurrent Spontaneous Fetal Loss (RSFL). Definisi RSFL adala tiga atau lebih keguguran berturut-turut pada umur kehamilan 20 minggu atau kurang atau dengan berat janin kurang dari 500g. Sekitar 40-50\% penyebab terjadinya RSFL sampai saat ini tidak dapat diidentifikasi. APS bertanggung jawab pada sekitar 16 - 36\% pasien dengan RSFL. ${ }^{4}$

Terjadinya RSFL pada APS adalah dikarenakan berbagai alasan yang meliputi pertumbuhan janin intrauterin yang terhambat (IUGR), preeklampsia, pemisahan plasenta prematur, DVT, HELLP dan DIC. Kariotipe janin dalam hal ini harus normal. Pasien dengan RSFL harus dilakukan pemeriksaan antibodi aPL. Banyak penelitian telah menunjukkan bahwa pengujian berulang mungkin diperlukan untuk meningkatkan sensitivitas dan spesifisitas diagnosis. ${ }^{5}$ 


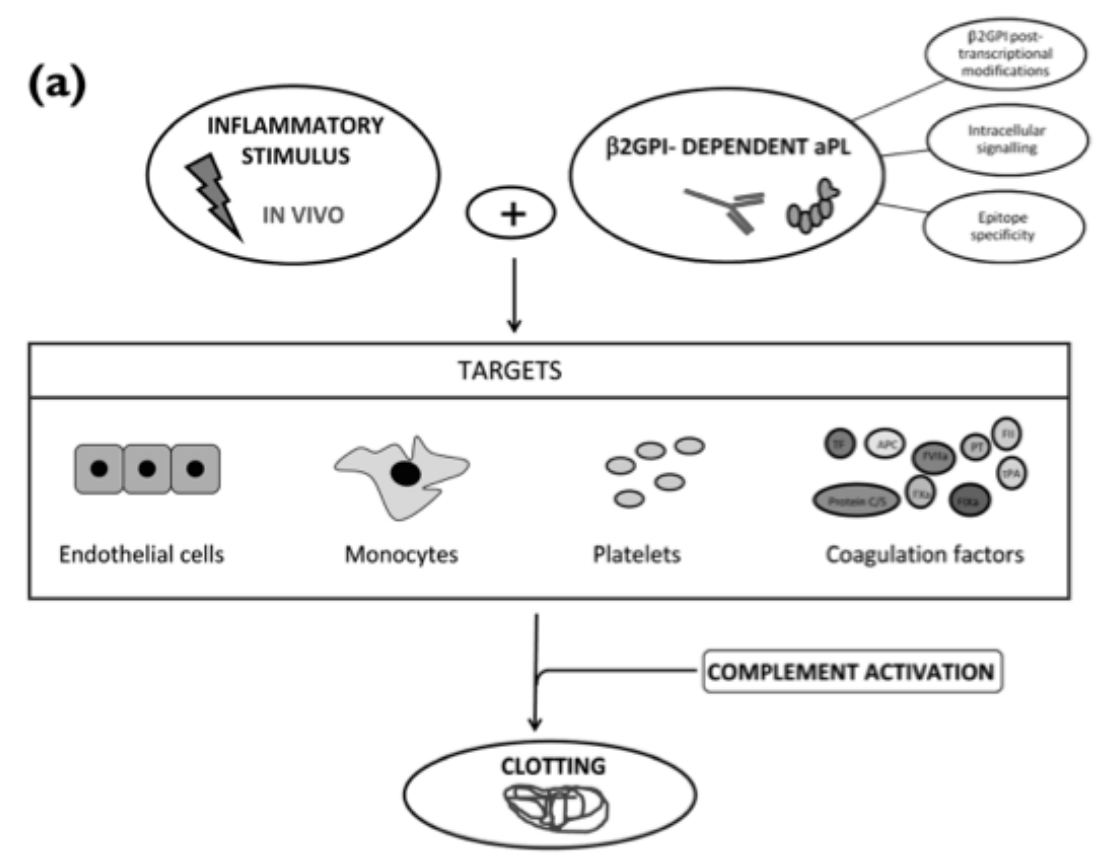

(b)

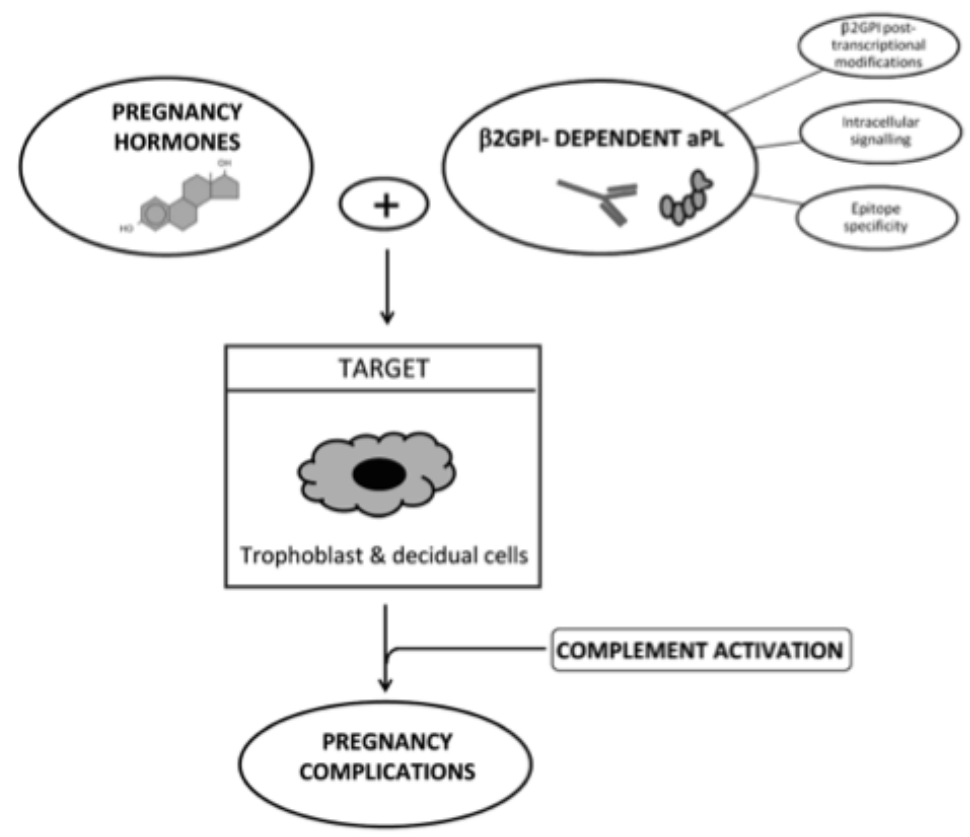

Gambar 2. Skema mekanisme patogenik sindrom anti-fosfolipid pada kehamilan. (a) Sindrom antifosfolipid (APS) vascular. Antibodi anti-fosfolipid (aPLs) dapat menargetkan jenis sel-sel yang

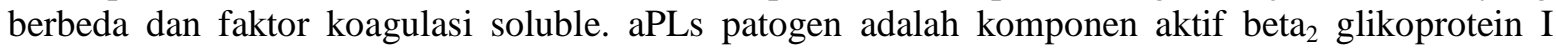
( $\beta 2 \mathrm{GPI})$ setelah stimulus inflamasi (paparan kedua). Variabel tambahan yang dapat memengaruhi patogenisitas aPL, adalah seperti kemampuan antibodi untuk memodulasi sinyal sel yang berbeda dan untuk menampilkan beragam spesifisitas epitop dan reaktivitas dengan $\beta_{2}$ GPI modifikasi. (b) APS pada kehamilan. $\beta_{2}$ GPI- bergantung aPLs dapat menargetkan trofoblas dan sel desidua. $\beta_{2} \mathrm{GPI}$ dapat berada pada tingkat uterus bahkan pada hewan yang tidak hamil dan dapat berikatan pada selsel trofoblas (sinsitiotrofoblas). Paparan kedua tampaknya tidak diperlukan, dan hormon wanita atau kehamilan itu sendiri bisa menjadi setara dengan paparan kedua seperti yang telah dijelaskan pada manifestasi vaskular. Seperti pada APS vaskular, kemampuan antibodi untuk memodulasi sinyal sel yang berbeda dan untuk menampilkan beragam spesifisitas epitop dan reaktivitas dengan $\beta 2 \mathrm{GPI}$ modifikasi dapat menjadi variabel tambahan yang dapat mempengaruhi patogenisitas aPL. APC, protein C aktif; FII, Faktor II; FIXa, Faktor IXa, FVIIa, Faktor VIIa; FXA, Faktor Xa; PT, protrombin; TF, faktor jaringan; TPA, faktor plasminogen jaringan. Sumber: Meroni et al, 2014. ${ }^{9}$ 
Peningkatan protein alpha feto maternal dan human chorionic gonadotropin sering ditemukan pada wanita dengan antibodi aPL (APA) dan secara signifikan berhubungan dengan kematian janin. ${ }^{4}$

Beberapa pemeriksaan laboratorium telah dipaparkan akhir-akhir ini. Walaupun tidak termasuk kriteria klasifikasi, beberapa jenis pemeriksaan masih berhubungan dengan dua protein utama fosfolipid yang diperkirakan ikut hadir bersama target antigen aPL yaitu $\beta_{2}$ GPI dan protrombin (PT). ${ }^{9}$

1. Antibodi anti-protrombin.

2. New assays for anti- $\beta_{2} G P I$ antibodies: the anti-domain antibodies $\beta_{2} G P I$, antidomain (D)I reactivity.

3. Antibodi terhadap phosphatidylethanol amine (PE)

4. Antibodi terhadap anionic phospholipids other than cardiolipin: PS, phosphatidyl inositol and phosphatidic acid.

5. Antibodi terhadap vimentin: Annexins

\section{Penanganan}

\section{Penanganan medikamentosa}

Antikoagulan

Pasien asimptomatik dengan antibodi positif diberikan antikoagulan jangka pendek ketika ancaman trombofilik seperti imobilisasi atau pembedahan akan dilakukan. ${ }^{4}$

Pasien dengan trombosis yang signifikan seperti DVT, iskemia arterial atau keguguran merupakan rekomendasi untuk diberikan antitrombotik. Sebagian besar pasien ini diberikan heparin. Regimen yang sering digunakan adalah pemberian low molecular weight heparin (ENOXAPARIN atau NADROPARIN 0.4 ml (40 mg - $3800 \mathrm{IU})$ ) diberikan subkutan dua kali sehari. Pasien harus tidak memiliki kontraindikasi pemberian heparin seperti risiko tinggi perdarahan atau riwayat trombositopenia akibat pemberian heparin. Pasien dengan insufisiensi renal diberikan unfractionated heparin yang dapat dihentikan segera bila terjadi perdarahan. ${ }^{4}$
Antikoagulan oral seperti warfarin diberikan secara tumpang tindih dengan pemberian heparin inisial yaitu pada hari keempat dan kelima sampai angka terapiutik INR tercapai. Percobaanpercobaan klinis telah menunjukkan intensitas standar penggunaan warfarin (target INR antara 2 dan 3) merupakan pilihan utama dibandingkan dengan penggunaan warfarin intensitas tinggi (INR antara 3,1 sampai 4 atau 4,5$){ }^{4}$

Setelah 12 minggu pengobatan, antibodi aPL harus kembali diukur untuk mengonfirmasi APS. Jika antibodi masih positif, penanganan dengan antikoagulan oral sebaiknya dilanjutkkan. Tes diagnostik untuk LA dapat menyebabkan positif palsu pada beberapa pasien yang sedang menjalani pengobatan dengan warfarin. Oleh karena itu dokter harus sebaiknya menghentikan pengobatan warfarin (beberapa hari) sebelum pengambilan sampel plasma. Penggunaan jangka panjang warfarin sangat direkomendasikan karena tingginya angka rekurensi. ${ }^{4}$

Pada percobaan klinis, pasien yang melanjutkan pengobatan dengan antikoagulan oral selama lebih dari 8 tahun tidak terjadi kekambuhan. Sedangkan pasien yang menghentikan penggunaan antikoagulan oral mengalami rekurensi tromboemboli $50 \%$ dalam 2 tahun dan sekitar $80 \%$ setelah 8 tahun. $^{4}$

Jika titer awal antibodi tinggi telah menjadi negatif setidaknya selama 6 bulan, dapat dipertimbangkan untuk penghentian antikoagulasi dengan syarat pasien tersebut tidak boleh memiliki risiko trombofilik lain dan harus dilakukan pengawasan yang ketat. $^{4}$

Penanganan APS dengan stroke iskemik yang efektif ialah dengan menggunakan baik aspirin atau warfarin intensitas standar (2-3). Pada trombus arterial non-serebral, kombinasi warfarin intensitas standar (2-3) dan aspirin $75 \mathrm{mg}$ direkomendasikan. Pasien dengan sindrom hipotrombinemia yang mengalami perdarahan atau membutuhkan operasi dapat diberikan terapi steroid dan Ig G intravena. ${ }^{4}$ 


\section{Kortikosteroid}

Terapi kortikosteroid sering menghentikan abnormalitas koagulasi dan trombositopenia imun pada APS. ${ }^{4}$

\section{Terapi tambahan lain}

Terapi tambahan seperti aspirin, kortikosteroid dan dosis obat imunosupresif seperti siklofosfamide tidak direkomendasikan secara rutin pada pasien yang sedang menjalani pengobatan dengan warfarin. Obat obat ini digunakan hanya bila terjadi trombosis rekuren dan iskemik. ${ }^{4}$

\section{Penanganan obstetrik}

Hasil yang memuaskan dapat dicapai pada wanita dengan RSFL yang mendapat penanganan. Pasien dengan abortus berulang dan kematian janin harus dilakukan pemeriksaan antibodi aPL. Pada pasien dengan antibodi aPL positif dan tidak diobati, keguguran dapat mencapai 90\%. Banyak obat termasuk aspirin, kortikosteroid dosis rendah dan antikoagulan telah dicoba. IgG intravena tidak memberikan keuntungan pada pasienpasien ini. Pasien dengan RSFL dan positif antibodi aPL sebaiknya diberikan konseling mengenai pengobatan. Kehamilan harus direncanakan. Aspirin $75 \mathrm{mg}$ sebaiknya dimulai satu atau dua bulan sebelum rencana konsepsi. LMWH segera diberikan pada saat kehamilan dikonfirmasi dengan ultrasonografi. Sampai saat ini masih terdapat kontroversi mengenai intensitas pengobatan menggunakan heparin. Untuk pasien dengan riwayat trombosis, dosis terapeutik heparin diindikasikan. ${ }^{4}$

LMWH contohnya Enoxaparin atau Nadroparin $0.4 \mathrm{ml}$ (40 mg, $3800 \mathrm{Iu})$ diberikan subkutan dua kali sehari (12 jam) sampai onset persalinan. Heparin dimulai sesaat setelah melahirkan. Warfarin dimulai dan bersamaan dengan heparin sampai target INR tercapai diantara 2,0 dan 3,0. Pada titik ini heparin dihentikan dan penggunaan antikoagulan oral dilanjutkan 3 sampai 6 bulan. ${ }^{4}$

Untuk pasien tanpa riwayat trombosis, heparin diberikan profilaksis (LMWH sekali sehari dengan dosis terapeutik). Untuk pasien yang tidak mampu mendapat LMWH, heparin konvensional atau unfractionated dapat digunakan dengan dosis 5000-10000 unit subkutan sehari atau dua kali sehari. Pengobatan ini memerlukan monitoring APTT dimana seharusnya menjadi dua kali dan dua setengah kali lipat nilai normal. Penggunaan LMWH tidak memerlukan monitoring. ${ }^{4}$

Dengan penanganan yang tepat, angka lahir hidup pada pasien dengan APS meningkat dari $0-40 \%$ menjadi $70-80 \%$. Aspirin meningkatkan prostasiklin dan menurunkan tromboksan A2. Selain efek antikoagulan, heparin juga memiliki efek antiinflamasi dan penghambatan dalam aktivasi komplemen; hal ini menguntungkan dalam terapi kehamilan dengan APS. ${ }^{4}$

\section{Penanganan khusus}

Hematoma spinal dapat disebabkan oleh penggunaan LMWH jika digunakan pada kehamilan khususnya pada pasien usia tua, penggunaan bersama sama dengan terapi antiplatelet dan jarum traumatik/ pemakaian kateter. ${ }^{4}$

Faktor yang paling penting yang mempengaruhi resiko perdarahan adalah jarak antara injeksi LMWH dan waktu penggunaan kateter/jarum. Pasien dengan antibodi aPL yang akan menjalani pembedahan sebaiknya menggunakan LMWH (dosis profilaksis) atau injeksi fondaparinaux 2,5 mg setiap hari dimulai 68 jam setelah operasi. ${ }^{4}$

\section{Penggunaan antikoagulan pada wanita menyusui}

Heparin dan LMWH tidak disekresikan ke dalam ASI dan dapat digunakan pada ibu menyusui secara aman. Warfarin aman digunakan setelah melahirkan dan menyusui, walaupun penggunaannya membutuhkan pengawasan yang ketat, kunjungan ke klinik lebih sering dan dapat menimbulkan risiko perdarahan post partum dan hematom perianal dibandingkan dengan LMWH. ${ }^{10}$ 


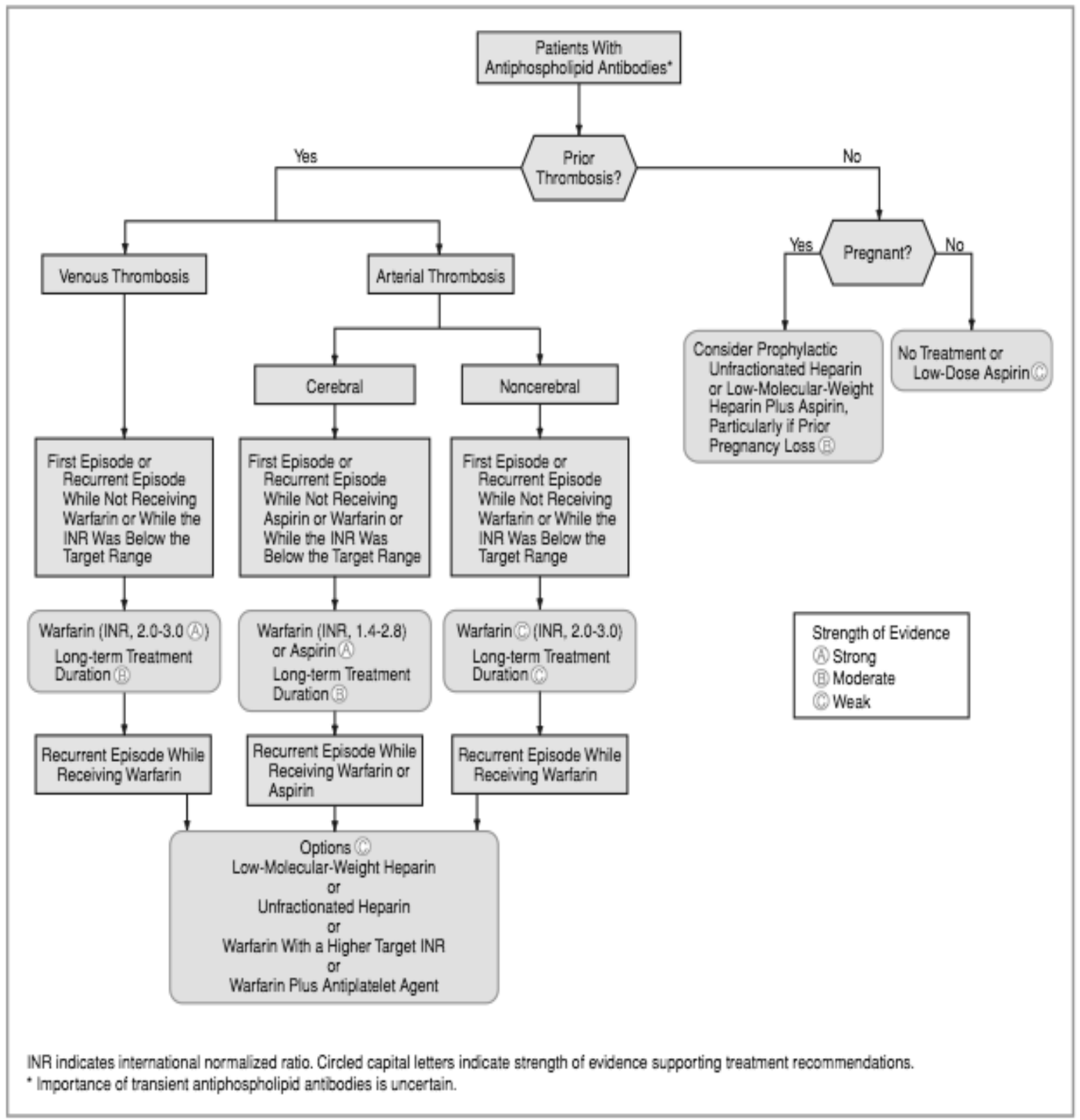

Gambar 3. Algoritma penanganan anti trombotik pada pasien dengan antibodi antifosfolipid. Sumber: Lim W et al, 2006. ${ }^{11}$

Warfarin tidak memberikan efek antikoagulan pada bayi yang menyusui. Oleh karena itu, penggunaan warfarin pada wanita postpartum yang membutuhkan terapi antikoagulan dapat dikategorikan aman dan wanita ini justru harus disarankan untuk tetap menyusui. ${ }^{12}$

\section{Kontrasepsi setelah melahirkan}

Kontrasepsi estrogen oral meningkatkan resiko thrombosis materal pada wanita dengan APAs dan SLE. ${ }^{10,13}$ Oleh karena itu penggunaan IUD lebih disarankan. Akan tetapi kontrasepsi yang hanya mengandung progesterone tidak meningkatkan resiko thrombosis. $^{14}$ Jika wanita dengan APS ingin hamil lagi, penanganan prekonsepsi harus dipertimbangkan. ${ }^{15}$

\section{Simpulan}

APS merupakan penyakit autoimun yang sering menyulitkan. Antibodi yang sering ditemukan dan terdeksi ialah LA, aCL, dan $\beta 2$ gp1. APS dapat terjadi secara 
primer maupun sekunder terhadap berbagai kondisi. Beberapa pasien dengan APS dapat tetap asimtomatik. Sebagian lainnya mengalami trombosis arteri dan vena atau RSFL.

Diagnosis meliputi kriteria klinis dan laboratorium. Pemeriksaan laboratorium tambahan telah dikembangkan dan digunakan untuk meningkatkan kekuatan prediksi dan diagnostik akan tetapi penemuan yang telah dilaporkan dan menjanjikan hanya terbatas pada antibodi anti PS/PT dan anti-DI. Pilihan penanganan lebih didasarkan pada evidence based.

\section{DAFTAR PUSTAKA}

1. Jo YY, Lee KC, Kim HS, Bae HK, Chang YJ. Anesthetic management of HELLP syndrome complicating primary antiphospholipid syndrome. Korean J Anesthesiol. 2012;6:575-8.

2. Ramli M. Seksio sesar pada penyakit autoimun. Workshop Anestesi Obstetri. Second Annual Symposium on Anesthesia Complication. Yogyakarta, 14-17 November 2012.

3. Belilos E, Diamond HS. Antiphospholipid syndrome [Internet]. 2012 [cited 2013 Feb 20]. Available from: http://emedicine.medscape.com/articl e/333221-overview

4. Mathew Thomas. Antiphospholipid Syndrome (ASP) An Update - Special Reference To Recurrent Spontaneous Pregnancy Loss (RSPL). Medicine Update 2011.

5. Espinosa G, Cervera R, Font J, Shoenfeld Y. Antiphospholipid syndrome: pathogenic mechanisms. Autoimmun Rev. 2003;2:86e93.

6. Greaves M. Antiphospholipid antibodies and thrombosis. Lancet. 1999;353: 1348-53.

7. Practice Committee. Recurrent pregnancy loss. Fertil Steril, 2012.

8. HELLP syndrome [Internet]. 2012 [cited 2013 Feb 20]. Available from: http://www.nlm.nih.gov/medlineplus/ ency/article/000890.htm

9. Meroni PL, Chighizola CB, Rovelli F, Gerosa M. Antiphospholipid syndrome in 2014: more clinical manifestations, novel pathogenic players and emerging biomarkers. Arthritis Res Ther. 2014;16:209.

10. Royal College of Obstetricians and Gynaecologists. Thromboprophylaxis during pregnancy, labour and after vaginal delivery. Guideline 2004; http://www.blackwellpublishing.com/ medicine/bmj/nnf5/pdfs/uk guidelines/ENOXAP ARIN.

11. Lim W, Crowther MA, Eikelboom JW. Management of anti- phospholipid antibody syndrome: a systematic review. JAMA. 2006;295:1050-1057.

12. Ginsberg JS, Greer I, Hirsh J. Use of antithrombotic agents during pregnancy. Chest. 2001;119(1 Suppl):122S-31S.

13. Duarte C, Ines L. Oral contraceptives and systemic lupus erythematosus: what should we advise to our patients? Acta Rheumatol Port. 2010; 35(2):133-40.

14. Erkan D, Patel S, Nuzzo M, Gerosa M, Meroni PL, Tincani A, et al. Management of the controversial aspects of the antiphospholipid syndrome pregnancies: a guide for clinicians and researchers. Rheumatology (Oxford) 2008;47 Suppl 3:iii23-iii27.

15. Reber G, Tincani A, Sanmarco M, de MP, Boffa MC. Proposals for the measurement of anti-beta2-glycoprotein I antibodies. Standardization group of the European Forum on Antiphospholipid Antibodies. J Thromb Haemost. 2004;2(10):1860-2. 